\title{
EROMOMMUMUA TEOPIO
}

\section{ОСОБЛИВОСТІ РЕАЛІЗАЦІЇ ІНВЕСТИЦІЙНОЇ ПОЛІТИКИ РЕСПУБЛІКИ БІЛОРУСЬ}

Герасенко В. П., Зикова А. А.

Актуальність теми: будучи частиною будь-якої економіки з ринковими відносинами, інвестиційна політика держави спрямована на формування і підтримку сприятливого середовища, що сприяє підвищенню інвестиційної активності, залучення вітчизняних та іноземних інвестицій, що займають особливе місце в забезпеченні доступу до фрінансових ресурсів, сучасним технологіям, інноваційним товарам, а також підвищенню рівня життя населення. Тому проблема розробки і реалізації інвестиційної політики в усіх регіонах країни є актуальною.

Постановка проблеми: на сучасному етапі розвитку білоруської економіки особливу увагу держави приділяється питанням залучення внутрішніх і іноземних інвестицій як додаткового джерела капіталу та технологій для розвитку національних виробництв і сорери послуд. Однак існує ряд проблем, що перешкоджають притоку інвестицій, вирішення яких зможе значно поліпшити інвестиційний клімат в країні.

Мета дослідження: дослідити рівень, динаміку і структуру інвестицій, що надходять в економіку Республіки Білорусь; визначити особливості реалізації, проблеми та шляхи вдосконалення інвестиційної політики Республіки Білорусь.

Методика дослідження: загальнонаукові і фрормалізовані - аналіз і синтез, індукція $і$ дедукція, статистичний, графічний, кореляція і регресія.

Результати дослідження: проведено аналіз надходження внутрішніх і іноземних інвестицій в економіку Республіки Білорусь, в результаті якого виявлено основні проблеми інвестиційної політики. Зроблено розрахунок інтервального прогнозу темпу зростання ВВП в залежності від темпу зростання інвестицій за допомогою побудованого рівняння регресії.

Область застосування результатів: результати дослідження можуть бути використані при розробці інвестиційної політики органами державного управління, а також в навчальному процесі економічних фракультетів ЗВО.

Ключові слова: інвестиції, інвестиційна політика, інвестиції в основний капітал, іноземні інвестиції, прямі іноземні інвестиції.

\section{ОСОБЕННОСТИ РЕАЛИЗАЦИИ ИНВЕСТИЦИОННОЙ ПОЛИТИКИ РЕСПУБЛИКИ БЕЛАРУСЬ}

Герасенко В. П. Зыкова А. А.

Актуальность темы: являясь частью любой экономики с рыночными отношениями, инвестиционная политика государства направлена на фрормирование и поддержание благоприятной среды, способствующей повышению инвестиционной активности, привлечению отечественных и 
иностранных инвестиций, занимающих особое место в обеспечении доступа к финансовым ресурсам, современным технологиям, инновационным товарам, а также повышению уровня жизни населения. Поэтому проблема разработки и реализации инвестиционной политики во всех регионах страны является актуальной.

Постановка проблемы: на современном этапе развития белорусской экономики особое внимание государства уделяется вопросам привлечения внутренних и иностранных инвестиций как дополнительному источнику капитала и технологий для развития национальных производств и сфреры услуг. Однако существует ряд проблем, препятствующих притоку инвестиций, решение которых сможет значительно улучшить инвестиционный климат в стране.

Цель исследования: исследовать уровень, динамику и структуру инвестиций, поступающих в экономику Республики Беларусь; определить особенности реализации, проблемы и пути совершенствования инвестиционной политики Республики Беларусь.

Методика исследования: общенаучные и формализованные - анализ и синтез, индукция и дедукция, статистический, графический, корреляция и регрессия.

Результаты исследования: проведен анализ поступления внутренних и иностранных инвестиций в экономику Республики Беларусь, в результате которого выявлены основные проблемы инвестиционной политики. Произведен расчет интервального прогноза темпа роста ВВП в зависимости от темпа роста инвестиций с помощью построенного уравнения регрессии.

Область применения результатов: результаты исследования могут быть использованы при разработке инвестиционной политики органами государственного управления, а также в учебном процессе экономических факультетов ВУЗов.

Ключевые слова: инвестиции, инвестиционная политика, инвестиции в основной капитал, иностранные инвестиции, прямые иностранные инвестиции.

\section{FEATURES OF INVESTMENT POLICY REALIZATION IN THE REPUBLIC OF BELARUS}

Gerasenko Vladimir, Zykava Hanna

Relevance of the topic: being a part of any economy with market relations, the state's investment policy is aimed at creating and maintaining a favorable environment conducive to increasing investment activity, attracting domestic and foreign investments, which occupy a special place in providing access to financial resources, modern technologies, innovative goods, and also improve the living standards of the population. Therefore, the problem of developing and implementing investment policy in all regions of the country is urgent.

Statement of the problem: at the present stage of development of the Belarusian economy, the state pays special attention to the issues of attracting domestic and foreign investment as an additional source of capital and technologies for the development of national industries and services. However, there are a number of problems that hinder the inflow of investments, the solution of which can significantly improve the investment climate in the country.

Purpose of the research: to study the level, dynamics and structure of investments in the economy of the Republic of Belarus; to determine the features of implementation, problems and ways to improve the investment policy of the Republic of Belarus.

Research methodology: general scientific and formalized - analysis and synthesis, induction and deduction, statistical, graphic, correlation and regression.

Research results: the analysis of the inflow of domestic and foreign investments into the economy of the Republic of Belarus was carried out, as a result of which the main problems of investment policy were identified. The calculation of the interval forecast of the GDP growth rate depending on the investment growth rate was carried out using the constructed regression equation.

Field of application of the results: the results of the study can be used in the development of investment policy by government bodies, as well as in the educational process of economic faculties of universities.

Key words: investments, investment policy, investments in fixed assets, foreign investments, foreign direct investments.

JEL Classification: E22, E27, E62

В современном понимании инвестиции представляются как неотъемлемая часть и необходимый фрактор обеспечения устойчивого экономического роста экономики любого государства. Рассматривая определения понятия «инвестиции», приведенные в различных словарях и учебниках, приходим к выводу, что в обобщенном виде справедливо следующее определение: «Инвестиции - вложение капитала, которое должно обеспечить сохранение и возрастание его стоимости и (или) принести положительную величину дохода».

Благодаря инвестициям осуществляется производство товаров и услуг с учетом новейших достижений науки и техники, что способствует совершенствованию технологий, повышению производительности труда, снижению издержек производства. Это, в свою очередь, благоприятно сказывается на деятельности предприятий, ведет к увеличению валового национального продукта, повышает активность страны на внешнем рынке. По этим причинам государственное регулирование инвестиционной деятельности является одним из основных направлений национальной экономической политики. А значит, проблема разработки и реализации инвестиционной политики в стране является актуальной. 
Под инвестиционной политикой государства понимается совокупность целенаправленных действий, проводимых государством по созданию благоприятных условий для всех субъектов хозяйствования с целью привлечения инвестиций, активизации инвестиционных процессов, подъема экономики, решения социальных проблем. Цель инвестиционной политики государства - реализация стратегии социальноэкономического развития страны, стимулирование инвестиционной деятельности для повышения эффрективности национальной экономики и устойчивого экономического роста [1, с. 24].

В Республике Беларусь проводится активная государственная политика по управлению инвестиционной сферой и привлечению инвестиций в страну. Министерство экономики Республики Беларусь является главным разработчиком и координатором государственной инвестиционной политики Республики Беларусь. Основные направления инвестиционной политики заложены в Государственной программе социально-экономического развития Республики Беларусь на 2016-2020 гг. и Национальной стратегии развития Республики Беларусь на 2030 г.

Стратегической целью инвестиционной политики Республики Беларусь является привлечение инвестиций в основной капитал и их приоритетное направление в инновации, производства с высокой добавленной стоимостью, развитие человеческого потенциала и сферы, призванные обеспечить экологическую и социально-экономическую безопасность страны.

Критериями достижения поставленной цели выступают:

- сохранение доли инвестиций в ВВП на уровне выше порогового значения (не менее 25 процентов) при повышении эффективности их использования;

- рост удельного веса таких источников фринансирования инвестиций, как собственные средства организаций и населения, иностранные инвестиции, при снижении доли средств консолидированного бюджета в общем объеме инвестиций в основной капитал;

- количество инвестиционных инфраструктурных проектов, реализуемых на принципах государственно-частного партнерства, - не менее 10 процентов;

- повышение рентабельности инвестиционных проектов [2, с. 140].

Заметим, что практическая реализация перечисленных стратегических критериев требует существенной инвестиционной активности. Поэтому необходимо активное привлечение отечественных частных и иностранных инвесторов. Привлеченные средства в приоритетном порядке направляются на коренную модернизацию действующих и на создание принципиально новых инновационных производств и предприятий, выпускающих наукоемкую, высокотехнологичную экспортоориентированную и импортозамещающую продукцию. В упрощенном смысле это означает инвестиции в основной капитал, т.е. совокупность затрат, направляемых на приобретение нового оборудования, внедрение передовой техники, модернизацию, что в итоге приводит к росту объема производства.

Так, по итогам 2019 года инвестиции в основной капитал составили 27,8 млрд рублей или 105,6\% в сопоставимых ценах к уровню прошлого года (в 2018 году по сравнению с 2017 годом инвестиции выросли на 6\%).

На рисунке 1 видно, что начиная с 2011 года прослеживается тенденция к снижению инвестиционной активности организаций Беларуси. Наиболее низкая инвестиционная активность отмечена в 2015 году, когда темп роста инвестиций в основной капитал в сопоставимых ценах составил 81,2\% к уровню 2014 г. При этом темп роста ВВП сложился на уровне 96,2\% по отношению к 2014 г., что являлось наиболее низким показателем за последние 10 лет. На снижение темпов роста инвестиций в основной капитал оказали влияние: сокращение объемов бюджетного фринансирования и размеров финансирования государственных программ, повышение цен в инвестиционной сфере, рост стоимости кредитных ресурсов.

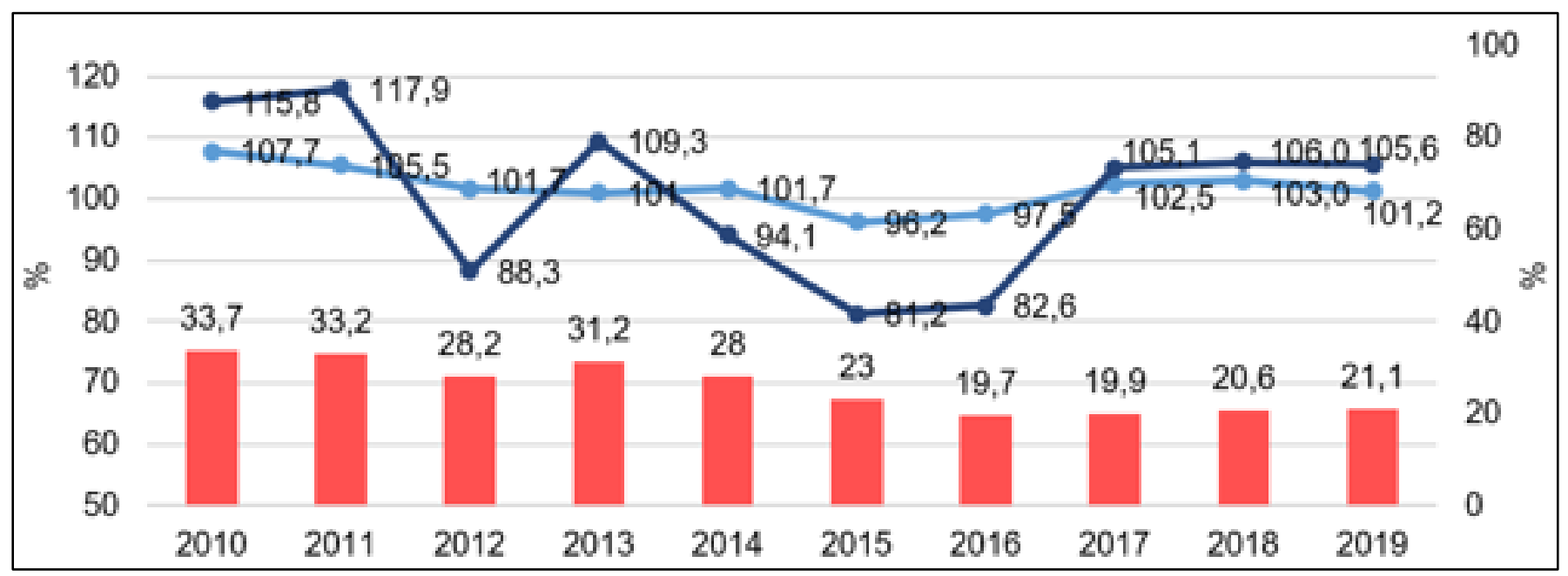

Рисунок 1. Динамика темпа роста ВВП, инвестиций в основной капитал, доли инвестиций в основной капитал в ВВП за 2010-2019 гг.

Источник: разработано автором на основе [3]. 
Качественную сторону инвестиционной активности характеризует показатель доли инвестиций в основной капитал в ВВП. При высоких значениях данного показателя в 2010-2011 годах (33,7 и 33,2\% соответственно) темп роста ВВП оставался примерно на одинаковом уровне (107,7 и 105,5\%). Начиная с 2014 года началось сокращение доли инвестиций в основной капитал в ВВП до уровня 19,7\% в 2016 году, при этом происходило и замедление темпов экономического роста. Однако затем наблюдалась положительная динамика как доли инвестиций в основной капитал в ВВП (до 21,1\% в 2019 г.), так и темпов роста ВВП (до $101,2 \%$ в 2019 г.).

Но даже при такой положительной тенденции не достигнуто сохранение доли инвестиций в ВВП на уровне выше порогового значения (не менее $25 \%$ ), что являлось одним из критериев достижения стратегической цели инвестиционной политики. Обнадеживает разве что скромный, но постоянный рост этого показателя.

Оценить степень влияния инвестиций в основной капитал на величину ВВП можно с помощью корреляционно-регрессионного анализа. Тесноту связи между анализируемыми показателями установим с помощью коэффрициента корреляции:

rxy = 0.85 - свидетельствует о сильной прямой корреляционной связи $(0,7-0,9)$, что позволяет продолжить анализ.

Так, исследуя зависимость темпа роста ВВП от темпа роста инвестиций в основной капитал за период 2010-2019 гг. получим следующее уравнение регрессии:

$\mathbf{y}=\mathbf{7 9 , 9 9 4}+\mathbf{0 , 2 2 x}$, где у - темп роста ВВП, а х - темп роста инвестиций в основной капитал.

На основании проведённых расчётов в Microsoft Excel и данного уравнения, можно сделать следующие выводы: с увеличением темпа роста инвестиций в основной капитал на 1\%, темп роста ВВП будет увеличиваться на $0,22 \%$.

Множественный коэффрициент корреляции, равный 0,85 , говорит о том, что наблюдается тесная прямая связь, т.е. с увеличением темпа роста инвестиций в основной капитал будет увеличиваться темп роста ВВП. Коэффициент детерминации, равный 0,73, показывает, что темп роста ВВП зависит на 73 \% от темпа роста инвестиций в основной капитал, а на остальные неучтённые факторы в модели приходится 27 \%. Проверка адекватности модели осуществляется с помощью расчета F-критерия Фишера. Его фактическое значение $(21,67)$ превышает табличное $(5,32)$, что позволяет нам отклонить нулевую гипотезу. То есть, уравнение является статистически значимым. Проведем оценку значимости параметров уравнения с помощью t-критерия Стьюдента: $|\mathrm{ta}|=16,94,|\mathrm{tb}|=4,65$, tкр $=2,31$. Видим, что фактические значения параметров превышают табличное значение, следовательно, они являются статистически значимыми.

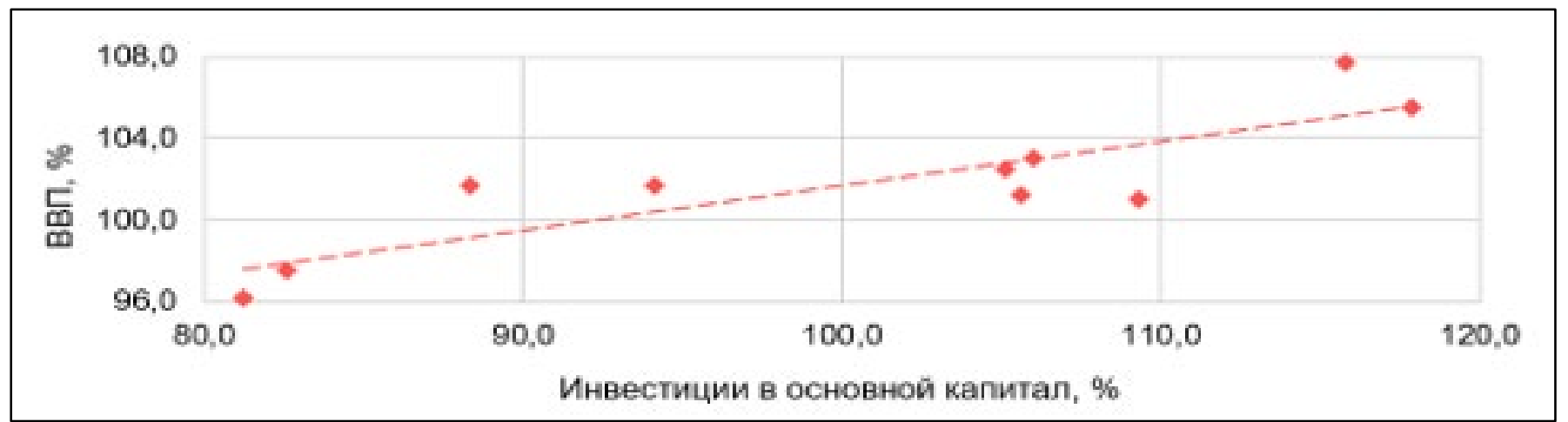

Рисунок 2. Корреляция между темпом роста ВВП и темпом роста инвестиций в основной капитал, 2010-2019 гг.

Источник: разработано автором.

Таким образом, привлечение инвестиций может увеличить объем совокупного капитала в стране, а значит, содействовать экономическому росту: рост инвестиций в основной капитал сопровождается ростом ВВП, и, напротив, сокращение инвестиционных потоков сопровождается снижением роста экономики.

Уравнение регрессии у = 79,99 + 0,22x, построенное на основе данных темпа роста ВВП от темпа роста инвестиций в основной капитал за период 2010-2019 гг., имеет хорошее качество, является адекватным, его можно использовать для прогнозирования.

В соответствии с постановлением Совета Министров Республики Беларусь от 27 декабря 2019 г. №921 «О задачах социально-экономического развития Республики Беларусь на 2020 год» [4], прогнозный темп роста инвестиций в основной капитал составляет 104,0 \% в сопоставимых ценах к 2019 году. В таком случае темп роста ВВП (упр) должен составить:

упр $=79,99+0,22 \times 104,0=102,87$ - в \% к соответствующему периоду 2019 года.

Рассчитаем ошибку прогноза по формуле:

$$
s_{\hat{y}}=s \cdot \sqrt{1+\frac{1}{n}+\frac{\left(x_{n p}-\bar{x}\right)^{2}}{n \cdot \sigma_{x}^{2}}}=1,85 \cdot \sqrt{1+\frac{1}{10}+\frac{(104-100,6)^{2}}{10 \cdot 174,93}}=1,94,
$$


где $\mathrm{s}$ - стандартная ошибка; $\mathrm{n}=10$ - количество наблюдений; $\bar{x}$ - среднее значение фактора х; $\sigma_{x}^{2}-$ дисперсия фрактора $\mathrm{x}$.

В этом случае предельная ошибка прогноза $\Delta_{\hat{y}}=t к p \cdot \mathrm{s}_{\hat{y}}=2,31 \cdot 1,94=4,48$, а доверительный интервал $\gamma_{\hat{y}}=102,87 \pm 4,48$.

Таким образом, был произведен расчет интервального прогноза с помощью построенного уравнения, где значение темпа роста ВВП с вероятностью 95\% должно находиться в пределах между 98,39 и 107,35 \% в сопоставимых ценах к 2019 году.

Повышение роли инвестиций в обеспечении стабильного макроэкономического роста непосредственно зависит от технологической структуры инвестиций в основной капитал: в ней должны преобладать инвестиции в активную часть основных средств - в машины, оборудование, транспортные средства.

Согласно рисунку 3 сохраняется высокий удельный вес затрат на строительно-монтажные работы (CMP) в технологической структуре инвестиций в основной капитал. Средний удельный вес в СМР за 20152019 гг. составил 51,0\%, что не способствует технико-технологическому совершенствованию производства.

Поэтому необходимо коренное изменение политики фрормирования технологической структуры инвестиций в сторону повышения доли затрат на приобретение машин, оборудования, транспортных средств. Данный показатель в 2019 году по Беларуси составил 39,8\%, т.е. в будущем необходимо обеспечить его увеличение до 50 \% от общего объема.

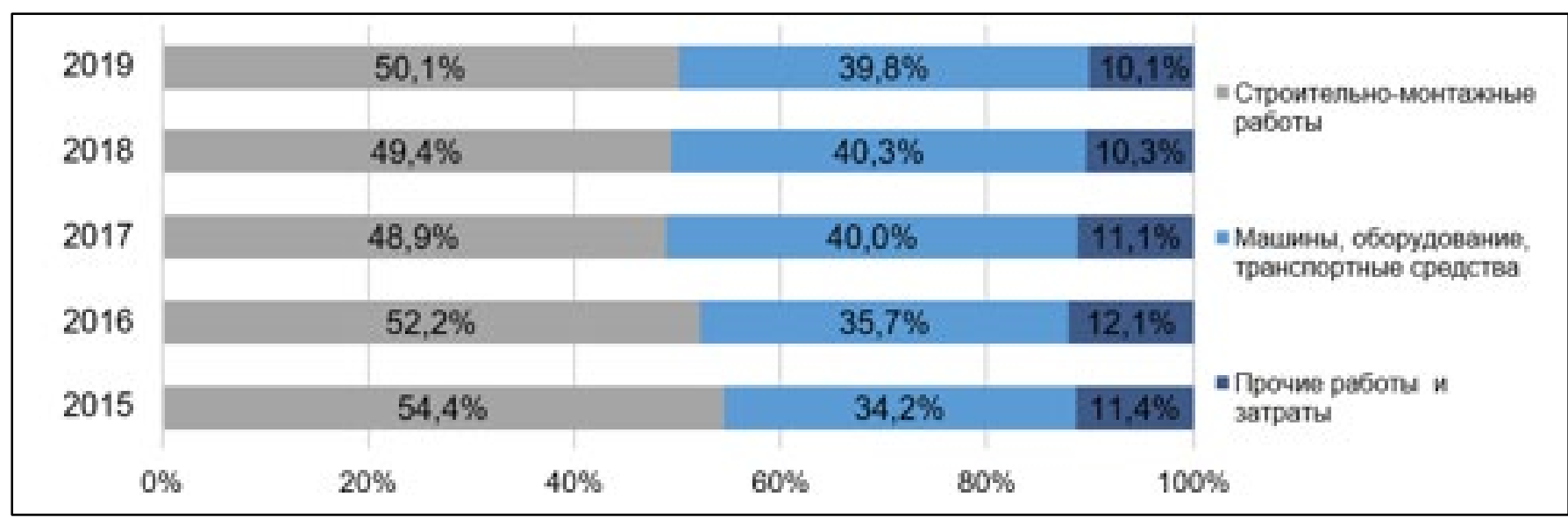

Рисунок 3. Технологическая структура инвестиций в основной капитал за 2012-2019 гг., \% Источник: разработано автором на основе [3].

Рассмотрим структуру инвестиций в основной капитал по формам собственности (рисунок 4). Высокий износ активной части основных фондов обусловливает необходимость использования для обновления не только государственные и собственные средства, но и иностранные инвестиции. Однако на рисунке 4 видно, что стабильно инвестиции в основной капитал иностранной формы собственности занимают незначительную долю совокупных инвестиций в основной капитал (7,8 \% и 8,7 \% в 2016 и 2019 году соответственно), что требует их привлечения.

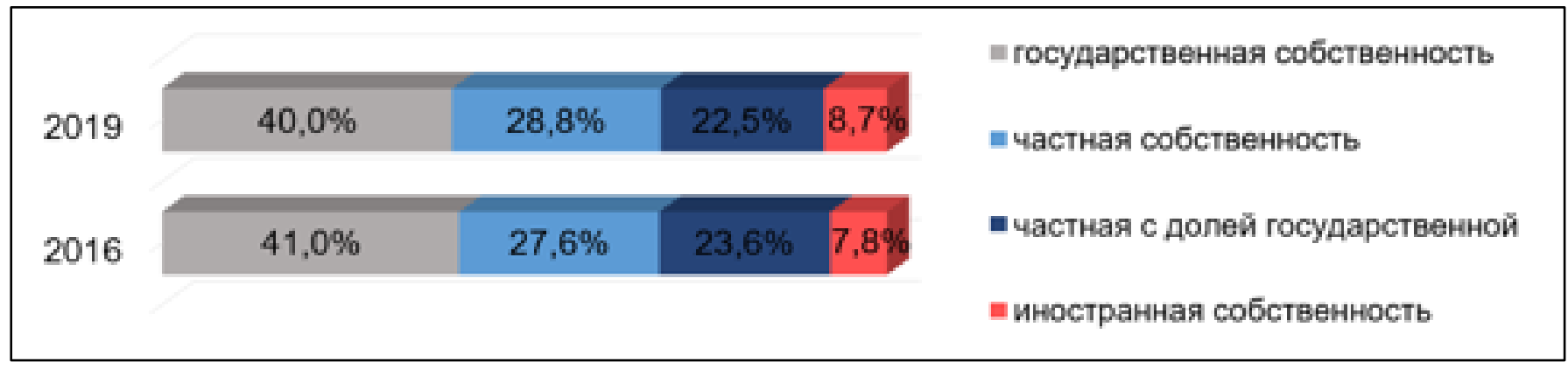

Рисунок 4. Инвестиции в основной капитал по формам собственности в 2016 и 2019 гг. Источник: разработано автором на основе [3].

Данные, приведенные в таблице 1, свидетельствуют о том, что наибольший удельный вес в источниках финансирования белорусских организаций занимают собственные средства организаций (40,1 \% в 2019 году), средства государства $(20,9 \%)$ и населения $(10,7 \%)$, кредиты банков $(13,4$ \%). При этом доля государственных средств растет - она изменилась за анализируемый период с 12,4 \% в 2011 году до 20,9 \% в 2019 году, что не соответствует критериям достижения стратегической цели инвестиционной политики. Доля банковских кредитов за этот период, наоборот, неуклонно снижается и изменилась с 35,8\% до 13,4\%. 
Таблица 1. Инвестиции в основной капитал по источникам финансирования

\begin{tabular}{|c|c|c|c|c|c|c|c|c|c|}
\hline Показатель & 2011 & 2012 & 2013 & 2014 & 2015 & 2016 & 2017 & 2018 & 2019 \\
\hline Всего инвестиций & 100 & 100 & 100 & 100 & 100 & 100 & 100 & 100 & 100 \\
\hline \multicolumn{10}{|l|}{ В том числе за счет: } \\
\hline консолидированного бюджета & 12,4 & 16,0 & 20,7 & 15,8 & 21,8 & 23,8 & 25,0 & 21,4 & 20,9 \\
\hline собственных средств организаций & 37,8 & 40,0 & 37,8 & 38,5 & 39,7 & 39,8 & 38,6 & 40,2 & 40,1 \\
\hline заемных средств других организаций & 0,6 & 1,5 & 1,2 & 1,5 & 1,3 & 1,3 & 1,2 & 1,0 & 1,0 \\
\hline средств населения & 5,9 & 6,8 & 8,3 & 10,0 & 12,2 & 12,6 & 11,9 & 11,7 & 10,7 \\
\hline иностранных инвестиций (без и & 3,0 & 3,2 & 3,2 & 3,7 & 3,9 & 5,0 & 5,0 & 4,5 & 4,9 \\
\hline кредитов банков (в том числе иностранных) & 35,8 & 26,5 & 24,2 & 26,6 & 17,2 & 13,7 & 12,9 & 14,0 & 13,4 \\
\hline прочих источников & 4,5 & 5,9 & 4,6 & 3,9 & 3,9 & 4,0 & 5,6 & 7,2 & 9,0 \\
\hline
\end{tabular}

Источник: разработано автором на основе [3].

Объемы инвестиций, направляемых в производственную сферу, составили 52,4\% к общему объему инвестиций в основной капитал в 2019 году. Данная статья состоит в основном из вложений инвестиций в промышленность (39,4\% к итогу). В сфере услуг в качестве решающего фрактора роста до 47,6\% выступает увеличение инвестиционных вложений в транспортную деятельность, здравоохранение, социальные услуги, спорт и творчество.

По итогам января-июня 2020 года в экономике республики было использовано 12,76 млрд рублей инвестиций в основной капитал или в сопоставимых ценах 98,8\% к уровню января-июня 2019 года. Удельной вес инвестиций в основной капитал к ВВП составил 19,3\%, что также не соответствует порогу экономической безопасности. В январе-июне 2020 года наибольшие объемы инвестиций в основной капитал использованы на реализацию инвестиционных проектов по строительству Белорусской АЭС, горно-обогатительного комбината Старобинского месторождения ИООО «Славкалий», третьей линии Минского метрополитена, проектов, реализуемых ОАО «Беларуськалий», ЗАО «БНБК», нефртеперерабатывающих предприятий [5].

Выходить на рост инвестиционной активности внутри страны можно путем привлечения внешних инвестиций. Приход иностранных инвестиций позволяет организовать производство новых товаров и открыть для белорусской продукции новые рынки сбыта. В сочетании это позволит повысить конкурентоспособность национальной экономики и создать основу для устойчивого экономического роста. Поэтому особое внимание уделим рассмотрению привлечения иностранных инвестиций в экономику страны.

Структуру и динамику привлеченных иностранных инвестиций можно наблюдать в таблице 2. Неравномерность притока иностранных инвестиций в 2010-2019 гг. свидетельствует о том, что они носят точечный характер, то есть поступают под конкретные проекты. Наиболее высокий объем инвестиций был привлечен в 2011 году (18,9 млрд долларов США), что было достигнуто в основном за счет прямых иностранных инвестиций. Такой резкий скачок обусловлен российскими инвестициями в белорусскую экономику, представляющими собой платежи ОАО »Газпром» в связи с приобретением пакетов акций совместного предприятия на базе собственности ОАО «Белтрансгаз» [6].

Всего в 2019 году в реальный сектор экономки Республики Беларусь поступило 10 006,8 млн долл. США валовых иностранных инвестиций, объем которых по сравнению с 2018 г. сократился на 835,2 млн долл. США или на $7,7 \%$.

Таблица 2. Поступление иностранных инвестиций в реальный сектор экономики Республики Беларусь по видам, 2011-2019 гг. (в млн долл. США и \%)

\begin{tabular}{|c|c|c|c|c|c|c|c|c|c|}
\hline \multirow{2}{*}{ Показатель } & \multicolumn{9}{|c|}{ Год } \\
\hline & 2011 & 2012 & 2013 & 2014 & 2015 & 2016 & 2017 & 2018 & 2019 \\
\hline Иностранные инвестиции & 18879 & 14330 & 14974 & 15084 & 11344 & 8560 & 9729 & 10842 & 10007 \\
\hline \multicolumn{10}{|l|}{ В том числе: } \\
\hline прямые инвестиции & 13248 & 10358 & 11083 & 10169 & 7241 & 6929 & 7634 & 8537 & 7233 \\
\hline портфоельные инвест & 2,3 & 23,4 & 12,2 & 10,6 & 5,1 & 2,8 & 8,4 & 3,9 & 6,7 \\
\hline прочие инвестиции & 5628 & 3948 & 3879 & 4905 & 4098 & 1629 & 2086 & 2301 & 2767 \\
\hline \multicolumn{10}{|c|}{ В процентах к итогу } \\
\hline Иностранные инвестиции & 100 & 100 & 100 & 100 & 100 & 100 & 100 & 100 & 100 \\
\hline \multicolumn{10}{|l|}{ В том числе: } \\
\hline прямые инвестиции & 70,2 & 72,3 & 74,0 & 67,4 & 63,8 & 80,9 & 78,5 & 78,7 & 72,3 \\
\hline портфельные инвестиции & 0,01 & 0,2 & 0,1 & 0,1 & 0,05 & 0.03 & 0.1 & 0,04 & 0,1 \\
\hline прочие инвестиции & 29,8 & 27,6 & 25,9 & 32,5 & 36,1 & 19,0 & 21,4 & 21,2 & 27,6 \\
\hline
\end{tabular}

Источник: собственная разработка на основе [3].

По итогам 2019 года 72,3 \% иностранных инвестиций, направленных в экономику Беларуси, поступили в форме прямых иностранных инвестиций. Объем ПИИ составил 7 233,2 млн долл. США, сократившись по сравнению с 2018 годом на 1303,9 млн долл. или на 15,3\%. В структуре ПИИ неизменно преобладают 
долговые инструменты, а также реинвестирование (повторное вложение прибыли после окончания периода инвестирования в тот же объект). Новые иностранные инвестиции в последние годы практически исчезли.

Объем портфельных инвестиций в 2019 году составил 6,7 млн долл. США (менее 0,1\% от общего объема). Портфельные иностранные инвестиции в Беларуси традиционно остаются на низком уровне в силу неразвитости белорусского фондового рынка и все еще невысокой активности как государственного, так и частного сектора в данной сфере. Ожидать увеличения потока иностранных портфельных инвестиций не приходится.

Прочие иностранные инвестиции поступили в экономику Беларуси в размере 2 766,9 млн долл. (27,6\% от общего объема), при этом их объем увеличился по сравнению с 2018 г. на 465,9 млн долл. или на 20,2\%. Однако следует учитывать, что прочие инвестиции, включающие торговые и другие кредиты, ссуды, займы дают эффект лишь в краткосрочной перспективе, так как через определенный период времени их необходимо возвращать и привлеченные средства вновь изымаются из экономики страны.

По данным Национального статистического комитета Республики Беларусь основными инвесторами в Беларуси в 2019 году выступали субъекты хозяйствования из России (45,1\% всех поступивших инвестиций), Великобритании $(18,0 \%)$, Кипра $(7,6 \%)$ и другие. Более детально поступление инвестиций по основным странам инвесторам можно увидеть на рисунке 5.

Страны, которые являются ключевыми инвесторами Республики Беларусь, остаются постоянными уже на протяжении нескольких лет. В стране наблюдается устойчивое доминирование российского капитала, в то время как присутствие инвесторов из других стран, в том числе развитых, пока является невысоким.

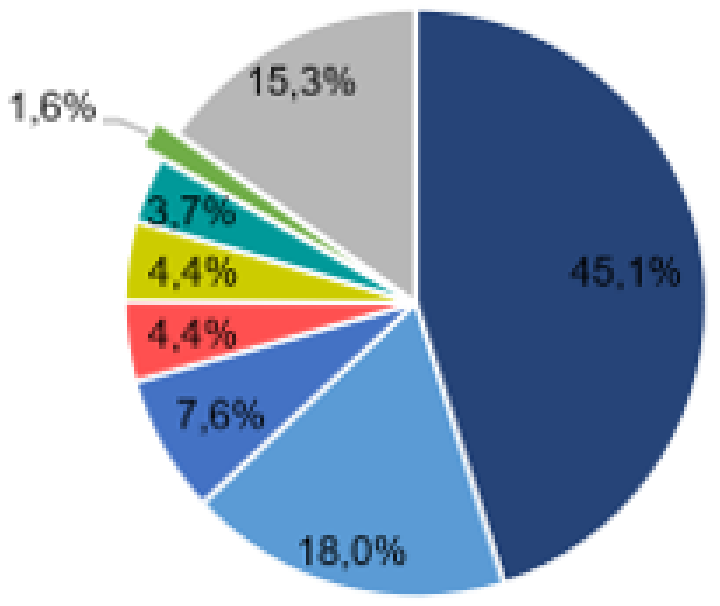

- Российская Федерация

" Великобритания

- Кипр

- Польша

- Австрия

- Украина

- Китай

- Остальные

Рисунок 5. Поступление валовых иностранных инвестиций в реальный сектор экономики Республики Беларусь по основным странам-инвесторам в 2019 году

Источник: разработано автором на основе [3].

Республика Беларусь гордится стратегическим партнерством с Китаем и присоединением Беларуси к инициативе «Один пояс - один путь». Но несмотря на тесное торгово-экономическое сотрудничество, доля китайских инвестиций в общем объеме поступивших иностранных инвестиций остается низкой и составила 1,6\% в 2019 году (162,2 млн долл.), сократившись вдвое относительно 2018 года.

С точки зрения отраслевого анализа, иностранные инвесторы наиболее активны в таких отраслях, как оптовая и розничная торговля, ремонт автомобилей и мотоциклов, транспортная деятельность, производство машин и оборудования, промышленность (рисунок 6).

Таким образом, иностранный капитал устремляется в основном в отрасли, обеспечивающие инвесторам гарантированные доходы, а также в отрасли с быстрой окупаемостью вложений. Зарубежные инвестиции практически не участвуют в создании в Беларуси современных высокотехнологичных производств и услуг, которые смогли бы коренным образом изменить сложившуюся внешнеэкономическую специализацию страны.

Для более точного учета прямых иностранных инвестиций, реально поступающих в экономику, национальной статистикой используется статистический показатель «прямые иностранные инвестиции на чистой основе» (далее - ПИИ на чистой основе). Это инвестиции без учета долговых инструментов: кредитов и займов, кредиторской и дебиторской задолженности, лизинга. Данный показатель характеризует объем прямого инвестирования в белорусскую экономику, который может быть достигнут без каких-либо значительных мер, направленных на стимулирование инвестиций, и без учета знаковых сделок. В среднем ежегодно в 2010-2019 годах в Беларусь привлекалось около 1,8 млрд долл. США прямых инвестиций из-за рубежа, доля которых в ВВП составляла примерно 3 процента. В 2019 году приток ПИИ на чистой основе составил 1 327,2 млн долл. США и сократился по сравнению с аналогичным периодом 2018 г. на 18,8\% [3]. 

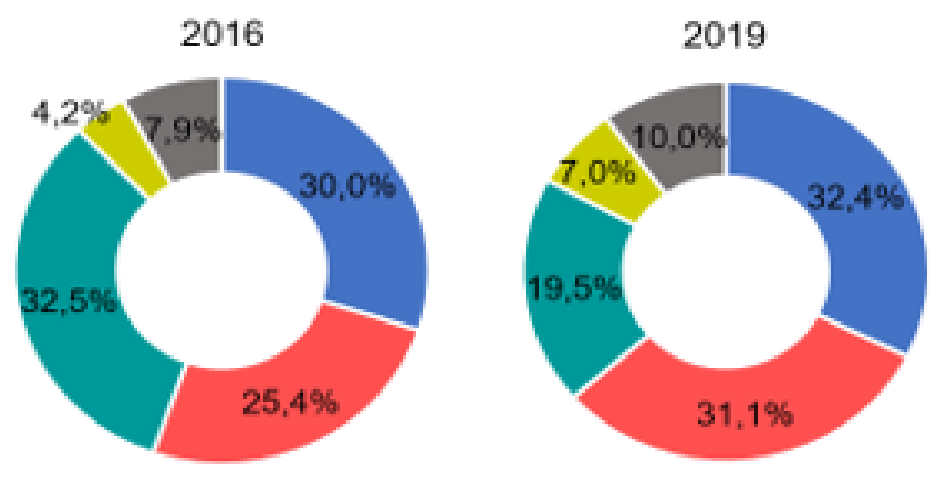

= Торговля

= Промышленность

- Транспортная деятельность

= Информация и связь

= Прочие

Рисунок 6. Структура поступивших валовых иностранных инвестиций в Беларусь по основным видам экономической деятельности в 2016 и 2019 гг. (в процентах к итогу)

Источник: разработано автором на основе [3].

Отмеченные результаты в привлечении ПИИ свидетельствуют, что, несмотря на ряд таких выгодных экономических условий, как близкое расположение к основным зарубежным рынкам (Европейского союза и стран СНГ), относительно низкий уровень оплаты труда среди стран региона, высокий уровень квалификации трудовых ресурсов и т.д., республика не смогла в полной мере реализовать имеющийся потенциал в привлечении ПИИ.

Всемирный экономический форум (World Economic Forum) обнародовал новый рейтинг конкурентоспособности стран (Global Competitiveness Index, GCl), где сопоставляются экономические возможности 141 государства. Беларусь традиционно в данном рейтинге отсутствует, что характеризуется отсутствием международной конкурентоспособности. Под конкурентоспособностью авторы доклада понимают способность страны сохранять высокие доходы, баланс хороших социально-экономических условий, включая удовлетворенность граждан качеством жизни. Таким образом, Республику Беларусь не рассматривают как возможного участника на международной инвестиционной карте [7].

Ключевой проблемой конкурентоспособности является то, что Беларусь - одна из немногих стран мира, которая не входит во Всемирную торговую организацию (ВТО), т.е. не имеет доступа на международные рынки. Республика Беларусь ведет переговоры по присоединению к ВТО вот уже 27 лет, начиная с 1993 года, когда впервые была подана заявка на присоединение Беларуси к Генеральному соглашению по торговле товарами (ГАТТ).

Другая проблема скрывается в высоком налогообложении. Так, по оценке PwC «Paying Taxes 2020» средний уровень налоговой нагрузки в Беларуси составил 53,3\% (в среднем в мире - 40,5\%), а налоговая нагрузка на фонд оплаты труда - 39\% (8-ая худшая страна в мире) [8].

В отчете Всемирного банка «Ведение бизнеса 2020» Республика Беларусь заняла 49-е место среди 190 экономик мира. Одновременно наша страна получила 74,3 балла из 100 возможных по показателю благоприятности условий ведения бизнеса. По сравнению с аналогичным рейтингом предыдущего года Беларусь опустилась сразу на 12 позиций. Наиболее высокие позиции Беларуси в рейтинге по индикаторам «регистрация собственности» (14-е место; год назад по этому индикатору Беларусь занимала 5-е место) и «подключение к системе электроснабжения» (в текущем рейтинге Беларусь сохранила 20-е место). Хуже всего результаты по позициям «получение кредитов» (104-я позиция), «налогообложение» (99-е место), «защита миноритарных инвесторов» (79-я позиция) [9].

В настоящее время существуют следующие проблемы, связанные с реализацией инвестиционной политики в Республике Беларусь:

- нестабильность и неопределенность законодательства, а также множественность правовых актов, регулирующих данную сфреру;

- низкая доля частного сектора и высокий уровень административного вмешательства в предпринимательскую деятельность;

- бюрократическая структура принятия решений государственными органами по согласованию и размещению инвестиций;

- неразвитость рынка ценных бумаг;

- отсутствие конкурентоспособности на международной арене.

Поэтому фактические результаты в сорере привлечения инвестиций по-прежнему не соответствуют экономическому потенциалу и потребностям страны. На современном этапе Беларусь уступает большинству стран по объемам инвестиций.

Ныне действующая в Беларуси инвестиционная политика по привлечению инвестиций не является оптимальной и нуждается в улучшении. Возможными путями решения существующих проблем являются:

- совершенствование законодательства в области налогового, кредитного, валютного, таможенного регулирования инвестиций, обеспечение стабильности законодательства и его согласованности на всех 
уровнях (для этого необходимо ориентироваться на международное законодательство, а также законодательство других стран, успешных в привлечении инвестиций);

- создание простых и понятных условий ведения бизнеса (обеспечение диалога бизнеса и государственных органов при разработке проектов нормативных правовых актов в сфрере осуществления инвестиционной политики);

- создание благоприятной административной среды для осуществления инвестиций и развития предпринимательской деятельности;

- поддержание благоприятной налоговой среды и ее совершенствование;

- создание полноценной инфраструктуры для осуществления инвестиций, включающую информационное обеспечение инвестиционной деятельности;

- рост темпов демонополизации и приватизации для повышения эффективности функционирования соответствующих отраслей и модернизации экономики в целом;

- обеспечение конкурентоспособных условий для привлечения инвесторов в рамках Евразийского экономического союза, а также инвесторов из экономически развитых стран, так как именно в этих странах базируются наиболее финансово мощные инвесторы;

- создание определённых условий для размещения в Республике Беларусь фрилиалов крупнейших иностранных банков и представительств международных компаний, что позволит значительно улучшить работу по привлечению финансовых ресурсов и обслуживанию инвестиционных потоков;

- развитие международного инвестиционного сотрудничества с ЕС, ВТО, международными финансовокредитными организациями [10, с. 22-23].

Проведенная исследовательская работа позволяет сделать вывод о том, что существующая в Беларуси инвестиционная политика по привлечению инвестиций не является оптимальной и нуждается в улучшении. Решение этой проблемы требует создания специальных условий организации инвестиционной деятельности, эффективно обеспечивающих привлечение и целевое использование инвестируемых средств. В этой связи важнейшим направлением государственной инвестиционной политики Республики Беларусь является привлечение иностранных инвестиций в экономику страны, либерализация внешнеэкономических связей и повышение межгосударственного сотрудничества.

\section{Список использованных источников}

1. Огородников, В. И., Алферов В. М., Епифанова Н. С. и др. Инвестиционная политика: Учебное пособие. Новосибирск: СИУ РАНХИГС, 2014. 226 с.

2. Национальная стратегия устойчивого социально-экономического развития Республики Беларусь на период до 2030 года. URL: http://belarp.by/media/2019/ns.pdf (даma доступа: 18.09.2020).

3. Официальная статистика. Национальный статистический комитет Республики Беларусь. URL: https://www.belstat.gov.by/ (дата доступа: 20.09.2020).

4. Постановление Совета Министров Республики Беларусь от 27 декабря 2019 г. №921 «О задачах социально-экономического развития Республики Беларусь на 2020 год». URL: https://economy.gov.by/uploads/files/macro-prognoz/Postanovlenie-27-12-2019.pdf (даma docmyna: 21.09.2020).

5. Результаты инвестиционной политики Министерства Экономики Республики Беларусь URL: https://economy.gov.by/ru/pezultat-ru/ (дата доступа: 20.09.2020).

6. Зыкова, А. А. Роль иностранных инвестиций в экономике Республики Беларусь. Национальная экономика Республики Беларусь: проблемы и перспективы развития: материалы ХII Междунар. науч.практ. конфр. студентов, Минск, 3-11 апр. 2019 г. Минск : БГЭУ, 2019. 357 с.

7. The Global Competitiveness Report 2019. World Economic Forum. URL: http://www3.weforum.org/docs/WEF_TheGlobalCompetitivenessReport2019.pdfg

8. Paying Taxes 2020: overall ranking and data tables: PwC. URL: https://www.pwc.com/gx/en/services/tax/ publications/paying-taxes-2020/overall-ranking-and-data-tables.html (dama доступа: 21.09.2020).

9. О результатах Республики Беларусь в отчете «Doing Business 2020». URL: https://openknowledge. worldbank.org/bitstream/handle/10986/32436/9781464814402.pdf (дата доступа: 20.09.2020).

10. Cmратегия привлечения прямых иностранных инвестиций в Республику Беларусь до 2035 года. URL: https://www.investinbelarus.by/press/Cmpamezuя.pdf (дата доступа: 22.09.2020).

\section{References}

1. Ogorodnikov, V. I., Alferov V. M., Epifanova N. S. and others. Investitsionnaya politika: Uchebnoe posobie [Investment policy: Textbook]. Novosibirsk: SIU RANEPA, 2014. 226 p.

2. Natsional'naya strategiya ustoychivogo sotsial'no-ekonomicheskogo razvitiya Respubliki Belarus' na period do 2030 goda [National strategy for sustainable social and economic development of the Republic of Belarus for the period up to 2030]. URL: http://belarp.by/media/2019/ns.pdf (access date: 18.09.2020).

3. Ofitsial'naya statistika [Official statistics]. National Statistical Committee of the Republic of Belarus. URL: https://www.belstat.gov.by/ (access date: 20.09.2020)

4. Postanovlenie Soveta Ministrov Respubliki Belarus' ot 27 dekabrya 2019 g. №921 «O zadachakh sotsial'noekonomicheskogo razvitiya Respubliki Belarus' na 2020 god» [Resolution of the Council of Ministers of the Republic of Belarus dated December 27, 2019 No. 921 «On the tasks of socio-economic development of the Republic of 
Belarus for 2020»]. URL: https://economy.gov.by/uploads/files/macro-prognoz/Postanovlenie-27-12-2019.pdf (access date: 21.09.2020).

5. Rezul'taty investitsionnoy politiki Ministerstva Ekonomiki Respubliki Belarus' [Results of the investment policy of the Ministry of Economy of the Republic of Belarus] URL: https://economy.gov.by/ru/pezultat-ru/ (access date: 20.09.2020).

6. Zykova, A. A. (2019). Rol' inostrannykh investitsiy v ekonomike Respubliki Belarus' [The role of foreign investments in the economy of the Republic of Belarus]. National Economy of the Republic of Belarus: Problems and Development Prospects: Materials of the XII Intern. scientific-practical conf. students, Minsk, 3-11 Apr. 2019. Minsk: BSEU, 357 p.

7. The Global Competitiveness Report 2019. World Economic Forum. URL: http://www3.weforum.org/docs/ WEF_TheGlobalCompetitivenessReport2019.pdfg

8. Paying Taxes 2020: overall ranking and data tables: PwC. URL: https://www.pwc.com/gx/en/services/tax/ publications/paying-taxes-2020/overall-ranking-and-data-tables.html (access date: 21.09.2020).

9. O rezul'tatakh Respubliki Belarus' v otchete «Doing Business 2020» [On the results of the Republic of Belarus in the report "Doing Business 2020»]. URL: https://openknowledge.worldbank.org/bitstream/handle/10986/ 32436/9781464814402.pdf (access date: 21.09.2020).

10. Strategiya privlecheniya pryamykh inostrannykh investitsiy v Respubliku Belarus' do 2035 goda [Strategy for attracting direct foreign investment in the Republic of Belarus until 2035]. URL: https://www.investinbelarus.by/ press/Strategy.pdf (access date: 22.09.2020).

\section{ДАНІ ПРО АВТОРІВ}

Герасенко Володимир Петрович, доктор економічних наук, профресор кафедри фінансів e-mail: gerasenko_v@mail.ru

Зикова Анна Андріївна, студентка 4 курсу фракультету фрінансів та банківської справи e-mail: anna.zykova.99@mail.ru

УО «Білоруський державний економічний університет»

Партизанський пр-т, 26, м Мінськ, Білорусь

\section{ДАННЫЕ ОБ АВТОРАХ}

Герасенко Владимир Петрович, доктор экономических наук, профессор кафедры фринансов e-mail: gerasenko_v@mail.ru

Зыкова Анна Андреевна, студентка 4 курса фракультета фринансов и банковского дела e-mail: anna.zykova.99@mail.ru

УО «Белорусский государственный экономический университет»

Партизанский пр-т, 26, г. Минск, Беларусь

\section{DATA ABOUT THE AUTHORS}

Gerasenko Vladimir, Doctor of Economics, Professor of the Department of Finance e-mail: gerasenko_v@mail.ru

Zykava Hanna, 4th year student of the Faculty of Finance and Banking

e-mail: anna.zykova.99@mail.ru

EE «Belarusian State Economic University»

Partizanskiy prospect, 26, Minsk, Belarus

\section{ЕВОЛЮЦІЯ ЕКОНОМІЧНОЇ ДУМКИ В КОНТЕКСТІ ПРОБЛЕМИ КРЕДИТУВАННЯ У ДРУГІЙ ПОЛОВИНІ XVII - СЕРЕДИНІ XIX СТ.}

Орлик М. В.

У статті було здійснено аналіз наукових здобутків представників класичної економічної школи другої половині XVII - середини XIX cm. у сорері кредитування через призму сучасності.

Meта роботи полягає у дослідженні еволюції поглядів на сутність та роль кредитування представниками класичної економічної школи у другій половині XVII - середині XIX cm.

Методи проведеного дослідження. Для вирішення поставлених метою завдань застосовувались як загальнонаукові, так і спеціальні методи наукового пізнання. У процесі написання статі використовувались системний та структурований підходи, методи узагальнення, аналізу, порівняння, синтезу та наукової абстракції.

Результати роботи. У статті було встановлено та проаналізовано еволюцію теоретичного осмислення проблеми кредитування в класичній економічній школі від їі заснування до початку реалізації їх теоретичних надбань на практиці в Російській імперії. 